\title{
Correction to: Allometric equations for estimating oil palm stem biomass in the ecological context of Benin, West Africa
}

\author{
Hervé Nonwègnon Sayimi Aholoukpè ${ }^{1} \cdot$ Bernard Dubos $^{2} \cdot$ Philippe Deleporte $^{3} \cdot$ Albert Flori $^{2}$. \\ Lucien Guillaume Amadji ${ }^{4}$ Jean-Luc Chotte ${ }^{5}$. Didier Blavet ${ }^{5}$
}

Published online: 15 December 2018

○) Springer-Verlag GmbH Germany, part of Springer Nature 2018

\section{Correction to: Trees (2018) 32:1669-1680} https://doi.org/10.1007/s00468-018-1742-8

A typographical error in the step-by-step procedure on page 1677 would lead to incorrect estimations of stem biomass.

In the formula to compute the curvature coefficient $\left(C_{\text {curv }}\right)$ in step 3 , in the left column of page 1677 , a "plus" sign should be replaced by a "minus" sign.

The correct formula is: $C_{\text {curv }}=0.84 \times$ $[\operatorname{Ln}(1+\mathrm{H} 33 / 0.6)-\mathrm{H} 33 / 2.1]$.

All the other steps are correct.

The original article can be found online at https://doi.org/10.1007/ s00468-018-1742-8.

Hervé Nonwègnon Sayimi Aholoukpè aholoukpeherve@yahoo.fr

1 Centre de Recherches Agricoles Plantes Pérennes, Institut National des Recherches Agricoles du Bénin, BP 01, Pobè, Benin

2 CIRAD, UPR Systèmes de pérennes, 34398 Montpellier, France

3 CIRAD, UMR Eco\&Sols (Ecologie Fonctionnelle \& Biogéochimie des Sols et des Agro-écosystèmes) INRA-IRD-SupAgro-CIRAD, Place Viala, 34060 Montpellier Cedex 2, France

4 Faculté des Sciences Agronomiques, Université d'Abomey-Calavi, FSA/UAC, BP 526, Cotonou, Benin

5 IRD, UMR Eco\&Sols (Ecologie Fonctionnelle \& Biogéochimie des Sols et des Agro-écosystèmes) INRA-IRD-SupAgro-CIRAD, Place Viala, 34060 Montpellier Cedex 2, France 